\title{
Detection and Molecular Characterization of Black Spot Disease of Papaya (Carica papaya L.) Incited byAsperisporium caricae (Speg.) Maubl
}

\author{
S. Shreedevasena ${ }^{1 *}$, S.K. Manoranjitham ${ }^{1}$, L. Rajendran ${ }^{1}$ and R. Parimaladevi ${ }^{2}$ \\ ${ }^{1}$ Department of Plant Pathology, ${ }^{2}$ Department of Agricultural Microbiology, Tamil Nadu \\ Agricultural University, Coimbatore -641 003, Tamil Nadu, India \\ *Corresponding author
}

\section{A B S T R A C T}

\begin{tabular}{|c|c|}
\hline $\begin{array}{l}\text { Ke y w or d s } \\
\text { Papaya, black spot, } \\
\text { Molecular } \\
\text { detection, } \\
\text { Asperisporium } \\
\text { caricae }\end{array}$ & $\begin{array}{l}\text { Black spot of papaya caused by Asperisporium caricae incidence was recorded in five } \\
\text { different localities viz., Pasur, Telungupalayam, Thondamuthur, Vedapatti and TNAU } \\
\text { orchard of Coimbatore district. Per cent disease severity (PDS) ranged from } 1 \text { to } 29 \text { per } \\
\text { cent on leaves. The fungal pathogen associated with black spot of papaya was isolated and } \\
\text { identified as Asperisporium caricae based on morphological characters. Severe disease } \\
\text { incidence was observed from November to January and no disease incidence was recorded }\end{array}$ \\
\hline Arti & conditions twenty days after inoculation. Molecular confirmation of Asperisporium \\
\hline $\begin{array}{l}\text { Accepted: } \\
\text { 07 May } 2019 \\
\text { Available Online: } \\
\text { 10 June } 2019\end{array}$ & $\begin{array}{l}\text { caricae through } 18 \mathrm{~S} \text { rRNA gene sequencing gave an amplicon size of } 560 \mathrm{bp} \text { size. The } \\
\text { isolate Asperisporium caricae was sequenced and submitted to NCBI database with the } \\
\text { accession number MK } 879405 \text {. The present study was aimed to characterize the pathogen } \\
\text { responsible for black spot of papaya and confirmation by molecular methods. }\end{array}$ \\
\hline
\end{tabular}

\section{Introduction}

Papaya (Caricae papaya L.) is one of the most important fruit crop cultivated in many parts of world, rich in vitamins, minerals and digestive fibres required for human health. It belongs to the family Caricaceae which is cultivated mostly in tropical and subtropical regions. India stands first in papaya production which is cultivated over an area of 1.39 million hectares with production of 5831.00 Metric Tonnes (MT). Among the states, Andhra Pradesh occupied highest production of 1288.58 Metric Tonnes followed by Gujarat (1241.25 MT) and Karnataka (527.86 MT) (Hort stat.2017). In Tamil Nadu the crop is cultivated in an area of 1.76 thousand hectares with the production of 403.19 MT in 2018. Popular varieties widely cultivated are Red lady, Sinta and Co 8.

Papaya crop is being affected by many fungal diseases (Anthracnose, powdery mildew, black spot, and brown spot), Bacterial diseases (Papaya dieback, Bacterical leaf 
spot) and viral diseases (Leaf curl, Papaya ring spot, Mosaic). Among the diseases black spot of papaya was the recent emerging disease which was first observed in the variety "Honey dew" at Chettali, Karnataka and later it was observed in Co 1 variety in palani hills during cooler months (Ullasa et al., 1978). Symptomatology of black spot of papaya were initially appeared on the upper surface of leaves as small water soaked spots, later these spots become greyish white in color and the corresponding lower side the leaves develop black velvety conidial mass around the lesions. Severely affected leaves shrivel, develop larger necrotic lesions, become brittle and finally die.

This leads to severe defoliation of the older leaves. In the fruits the symptoms were small dot like spots appear initially, later they enlarge up to 2-6 $\mathrm{mm}$ in diameter. The spots are confined to the outer rind of the fruit which reduce the market value of exported fruit (Thiribhuvanamala et al., 2016). With this background information, the present study was carried out to isolate and characterize the papaya black spot pathogen Asperisporium caricae.

\section{Materials and Methods}

\section{Assessment of disease incidence}

Black leaf spot of papaya were recorded in five different localities of Coimbatore district during 2018-2019. Disease incidence was recorded in Thondamuthur $\left(10.5923^{\circ} \mathrm{N}\right.$ and $\left.76.50274^{\circ} \mathrm{E}\right)$, Pasur $\left(11.2732^{\circ} \mathrm{N}\right.$ and $\left.77.1204^{\circ} \mathrm{E}\right)$, Telungupalayam $\left(10.5935^{\circ} \mathrm{N}\right.$ and 76. $5556^{0}$ E), Vedaipatti $\left(11.0849^{0} \mathrm{~N}\right.$ and $\left.76.5332^{\circ} \mathrm{E}\right)$ and TNAU orchard $\left(11.01038^{\circ} \mathrm{N}\right.$ and $76.9333^{\circ} \mathrm{E}$ ) in the cultivars Co 8 and Red lady. The per cent disease severity was determined using standard scoring system developed by Inglis et al., 1988 using 0-5 scale.
The proportion of leaf area showing symptoms were recorded using a scale of 0 to 5 as follows, $0=$ No disease, $1=1-10 \%$ leaflet area with lesions, $2=11-25 \%$ leaflet area with lesions, $3=26-50 \%$ leaflet area with lesions and limited chlorosis, $4=$ Over $50 \%$ or more of the leaflet area with lesions and extensive necrosis, $5=$ Defoliation.

\section{Isolation and purification of pathogen}

The fungal pathogen was isolated from the black spot infected leaves of papaya var "Red lady" showing typical symptoms.

The infected leaves were cut into small pieces of $1.0-1.5 \mathrm{~cm}$, surface sterilized with $0.1 \%$ sodium hypochloride for one minute and washed thrice in the double distilled water.

The sterilized leaf bits were dried on the sterilized filter paper. The dried infected leaf bits were dried in a Petriplate containing potato dextrose agar amended with antibiotic. The culture plates were incubated at $24^{\circ} \mathrm{C}$ with a $12 \mathrm{~h}$ light/dark light conditions.

\section{Morphological characterization of A.carica}

The pure culture of $A$. caricae was sub cultured on PDA medium on Petri dishes (90 $\mathrm{mm}$ in diameter) for phenotypic and growth characters. Colony colour and texture observations were recorded at twenty days after incubation. The colony character and conidia morphology of the isolated fungus were studied (Minnis et al., 2011).

The conidia were scraped from infected leaves and mounted in lactophenol solution on a microscopic slide. Measurements of the conidia were made using a light microscope (Labomed-IVU 5100) and photographed using a Labomed camera model LX400 with an image analyser - pixelpro programme. 


\section{Pathogenicity}

Red lady papaya seedlings were raised under glasshouse condition in Tamil Nadu Agricultural University. For inoculation, 30 days old mycelium was carefully scrapped from culture plate and suspended in a sterile distilled water. The final concentration of conidia was adjusted to $5 \times 10^{5} \mathrm{ml}^{-1}$.

The conidial suspension of $10 \mathrm{ml}$ was taken and diluted in sterile water and it was applied on three month old papaya seedlings using hand sprayer during evening hours and the control plants were sprayed with sterile distilled water.

After inoculation, the plants were covered with pin pricked polyethene bags for 48 hours to maintain 80 per cent relative humidity. The symptoms were visible after 20-24 days of inoculation (Cumagun and Padilla, 2007).

\section{Molecular characterization}

The fungus was subjected for molecular characterization by sequencing the $18 \mathrm{~S}-28 \mathrm{~S}$ rRNA genes. The genomic DNA was extracted by Cetyl Trimethyl Ammonium Bromide (CTAB) method. (Minnis et al., 2011)

\section{Amplification by ITS universal primers}

The genomic DNA was used as a template and subjected for PCR amplification of 18S28S rRNA gene. The primers used were ITS1 (5'-AGAGTTTGATCCTGGCTCAG-3') and ITS4 (5'GGTTACCTTGTTACGACTT-3') with an initial denaturation of $95^{\circ} \mathrm{C}$ for $1 \mathrm{~min}$, followed by 35 cycles of denaturation at $95^{\circ} \mathrm{C}$ for $60 \mathrm{sec}$, annealing at $55^{\circ} \mathrm{C}$ for $1 \mathrm{~min}$, extension at $72^{\circ} \mathrm{C}$ for $1 \mathrm{~min}$ and final extension at $72^{\circ} \mathrm{C}$ for $3 \mathrm{~min}$ in nexus gradient Mastercycler showed the amplicon size of approximately $560 \mathrm{bp}$. (Minnis et al., 2011)

\section{Results and Discussion}

\section{Survey for the assessment of black spot of} papaya

Field visits were conducted at the five different locations of Coimbatore district. Highest per cent disease severity of black spot was observed in Pasur var "Red lady" with a maximum disease severity of 31.67 PDI on leaves followed by 30.62 PDI in TNAU orchard. Lowest incidence was recorded in Thondamuthur with a PDI of 16.67 at "CO 8" papaya. Older leaves were found to be more susceptible than younger leaves. The pathogen responsible for this disease was isolated from the infected samples and it was confirmed as A.caricae which causes black spot. On the upper surface of the leaves a white spot with yellow margin was observed corresponding to the lower surface black colour spot was observed (Fig. 1a; 1b). Infection on the matured fruit showed black spots confined to the outer rind of fruit which reduces the market value (Fig. 1c).

\section{Cultural characters}

The colonies on potato dextrose agar were near dark green to black in colour. Mycelium formed a raised mound covered with whitish, short erect hyphae or whitish aerial hyphae. Surface slightly velutinous with scattered black spherical structures. Hyphae are branched with walls smooth, hyaline to brownish, septate, 3-6.5 $\mu \mathrm{m}$ diameter. The conidial production on potato dextrose agar were sparsely distributed. Sporulation usually occurred after a month at $24{ }^{\circ} \mathrm{C}$ with a $12 \mathrm{~h}$ light/ dark regimen.

\section{Morphological characters}

Black spots are fruti colous scattered of 3-4 $\mathrm{mm}$ diam. Sporodochia were immersed on stromata. Sporodochia were erumpent, 
punctiform, blackish in colour. Brownish septated hyphae of 3-6.5 $\mu \mathrm{m}$ diameter. On the darkly pigmental stromata, the sporodochia were arranged densely to loosely. Conidiophores were simply straight branched, brown coloured with smooth septum. Conidiogenous cell occurs at terminal portion of conidiophores which were dark pigmented, cylindrical to clavate, polyblastic in nature. Conidia were initially hyaline later turn brown, 0-2 septate with verrucose margin. Hilum were thickened with dark in nature, usually present as base of conidia.

Table.1 List of surveyed areas of severity of black spot of papaya

\begin{tabular}{|c|l|r|r|r|r|c|}
\hline S.no & Place of survey & Latitude & Longitude & Variety & Age (months) & $\begin{array}{c}\text { Per cent severity on } \\
\text { leaves }\end{array}$ \\
\hline $\mathbf{1}$ & TNAU, orchard & $11.0103^{0} \mathrm{~N}$ & $76.9333^{0} \mathrm{E}$ & Co 7 & 4 & 23.33 \\
\hline $\mathbf{2}$ & TNAU, orchard & $11.0103^{0} \mathrm{~N}$ & $76.9333^{0} \mathrm{E}$ & Red lady & 6 & 30.62 \\
\hline $\mathbf{3}$ & TNAU, orchard & $11.0103^{0} \mathrm{~N}$ & $76.9333^{\circ} \mathrm{E}$ & $\mathrm{Co} 8$ & 5 & 18.33 \\
\hline $\mathbf{3}$ & Pasur & $11.2732^{0} \mathrm{~N}$ & $77.1204^{0} \mathrm{E}$ & Red lady & 4 & 31.67 \\
\hline $\mathbf{4}$ & Telungupalayam & $10.5935^{0} \mathrm{~N}$ & $76.5556^{0} \mathrm{E}$ & Red lady & 5 & 25.00 \\
\hline $\mathbf{5}$ & Thondamuthur & $10.5923^{0} \mathrm{~N}$ & $76.5027^{0} \mathrm{E}$ & $\mathrm{Co} 8$ & 5 & 16.67 \\
\hline $\mathbf{6}$ & Vedaipatti & $11.0849^{0} \mathrm{~N}$ & $76.5336^{\circ} \mathrm{E}$ & Red lady & 3 & 21.67 \\
\hline
\end{tabular}

Table.2 Pathogenicity test of Asperisporium caricae and symptom development on leaves up to 42 days

\begin{tabular}{|c|c|c|c|c|c|c|c|}
\hline \multirow[t]{2}{*}{ Sl.no } & \multirow[t]{2}{*}{ Variety } & \multicolumn{6}{|c|}{ Disease severity \% } \\
\hline & & 7 DAI & 14 DAI & 21 DAI & 28 DAI & 35 DAI & 42 DAI \\
\hline 1 & Co 7 & $\begin{array}{c}0 \\
(0.71)^{\mathrm{c}}\end{array}$ & $\begin{array}{c}0 \\
(0.71)^{\mathrm{c}}\end{array}$ & $\begin{array}{c}3.33 \\
(1.96)^{\mathrm{c}}\end{array}$ & $\begin{array}{c}6.67 \\
(2.68)^{\mathrm{c}}\end{array}$ & $\begin{array}{c}8.33 \\
(2.97)^{\mathrm{c}}\end{array}$ & $\begin{array}{c}18 \\
(4.30)^{\mathrm{c}}\end{array}$ \\
\hline 2 & Co 8 & $\begin{array}{c}0 \\
(0.71)^{\mathrm{d}}\end{array}$ & $\begin{array}{c}0 \\
(0.71)^{\mathrm{d}}\end{array}$ & $\begin{array}{c}1.67 \\
(1.47) \mathrm{d}\end{array}$ & $\begin{array}{c}3.33 \\
(1.95) \mathrm{d}\end{array}$ & $\begin{array}{c}6.67 \\
(2.68)^{d}\end{array}$ & $\begin{array}{c}15 \\
(3.93)^{\mathrm{d}}\end{array}$ \\
\hline 3 & Red lady & $\begin{array}{c}0 \\
(0.71)^{\mathrm{a}}\end{array}$ & $\begin{array}{c}2.8 \\
(1.82)^{\mathrm{a}}\end{array}$ & $\begin{array}{c}6.67 \\
(2.68) \mathrm{a}\end{array}$ & $\begin{array}{c}10 \\
(3.24)^{\mathrm{a}}\end{array}$ & $\begin{array}{c}11.66 \\
(3.49)^{\mathrm{a}}\end{array}$ & $\begin{array}{c}24 \\
(4.95)^{\mathrm{a}}\end{array}$ \\
\hline 4 & $\begin{array}{c}\text { Coorg } \\
\text { honey } \\
\text { dew }\end{array}$ & $\begin{array}{c}0 \\
(0.71)^{\mathrm{b}}\end{array}$ & $\begin{array}{c}2.2 \\
(1.64)^{b}\end{array}$ & $\begin{array}{c}5 \\
(2.34)^{b}\end{array}$ & $\begin{array}{c}8.57 \\
(3.01)^{b}\end{array}$ & $\begin{array}{c}11.42 \\
(3.45)^{b}\end{array}$ & $\begin{array}{c}20 \\
(4.52)^{b}\end{array}$ \\
\hline & SD & - & 0.006 & 0.009 & 0.010 & 0.011 & 0.014 \\
\hline & $\mathrm{CD}$ & - & 0.32 & 0.40 & 0.131 & 0.15 & 0.16 \\
\hline
\end{tabular}


Fig.1 Black spots on the lower surface of the leaf, (b) White spots with yellow margin on the upper surface of leaf (c) Black spots on the fruits
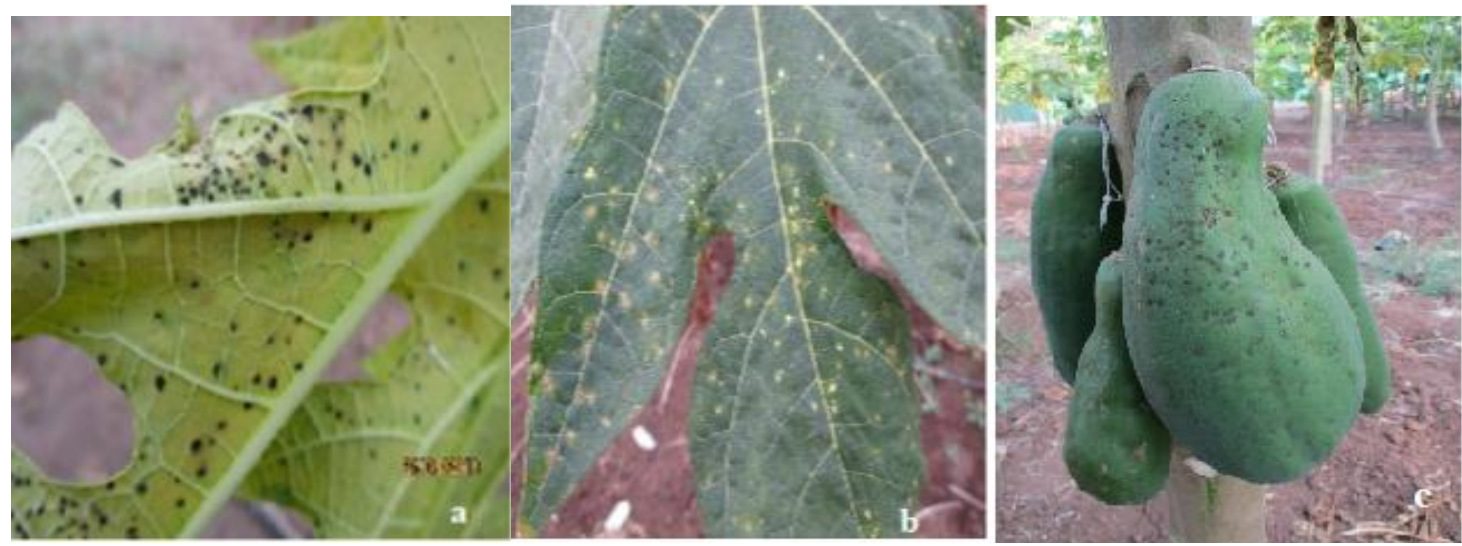

Fig.2 Morphological and cultural characteristics of Asperisporium caricae.(a) Colony of Asperisporium caricae on PDA (b) Mycelium of A.caricae (c) Conidia and Spermatia
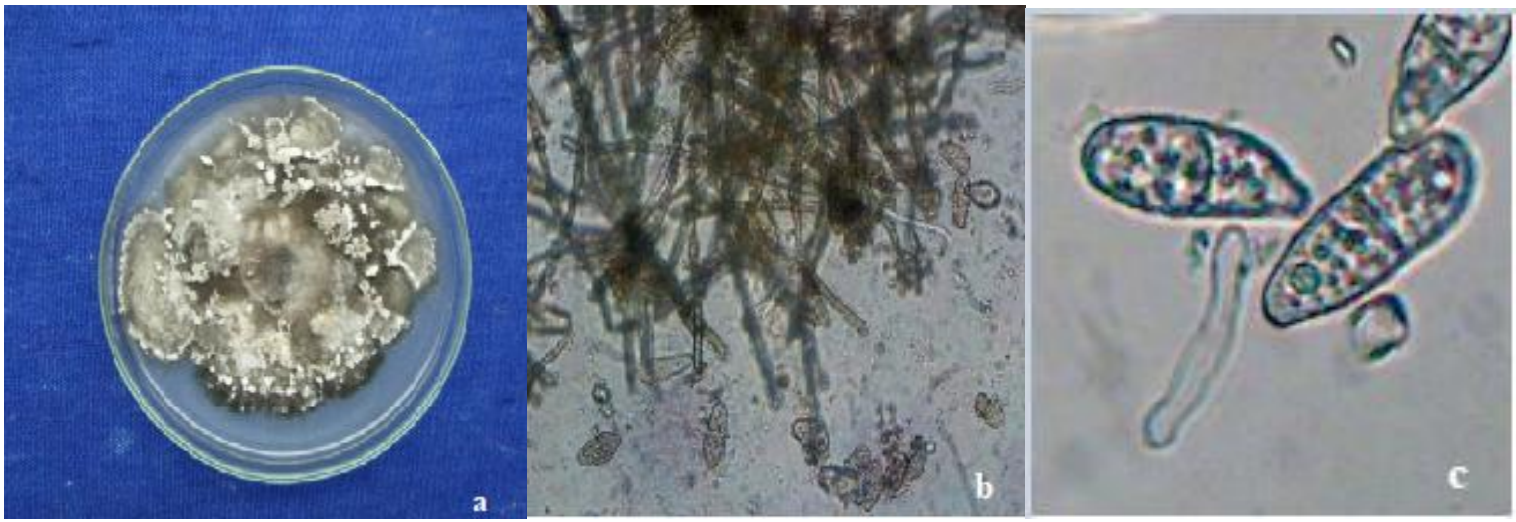

Fig.3 Pathogenicity test (b) symptom expression on the upper surface of leaf 20 DAI (c) symptoms on the lower surface the leaf at $20 \mathrm{DAI}$
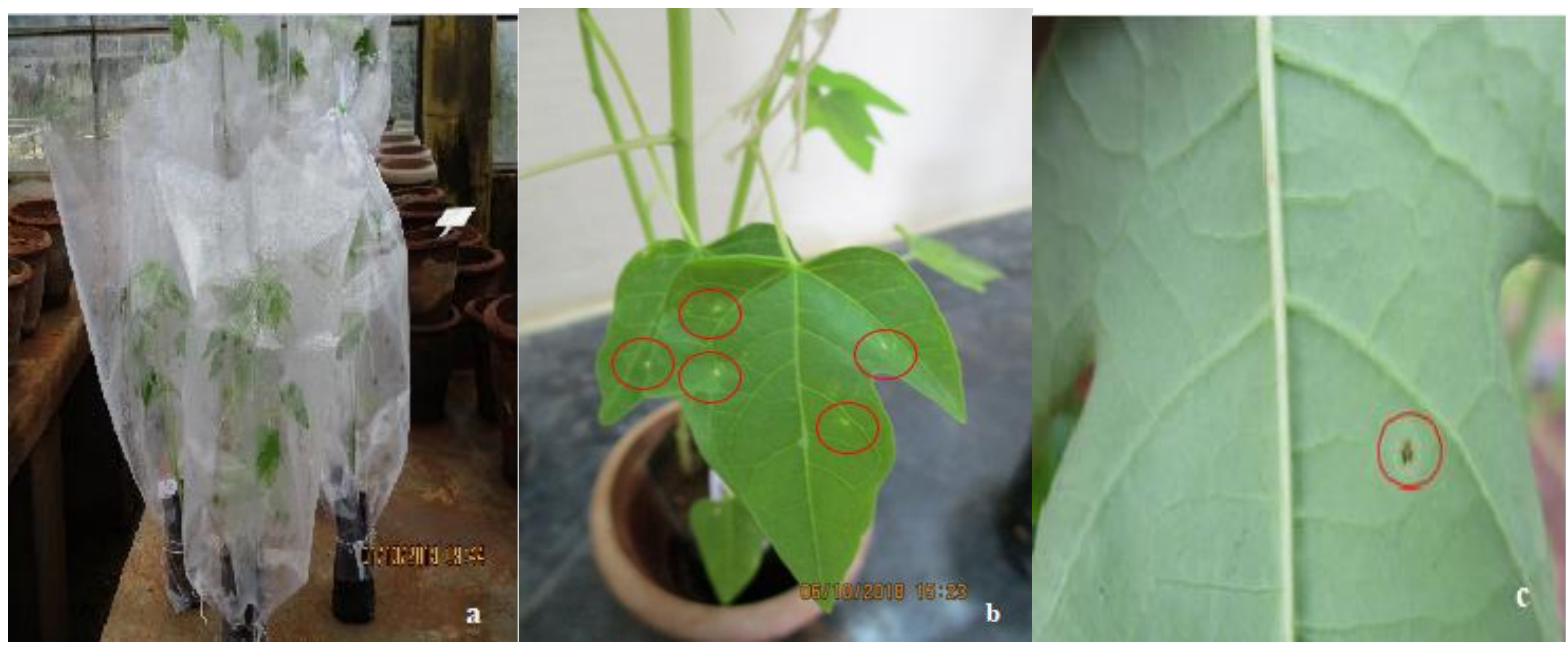
Fig.4 PCR amplification of 18S-28S rRNA gene of A.caricae

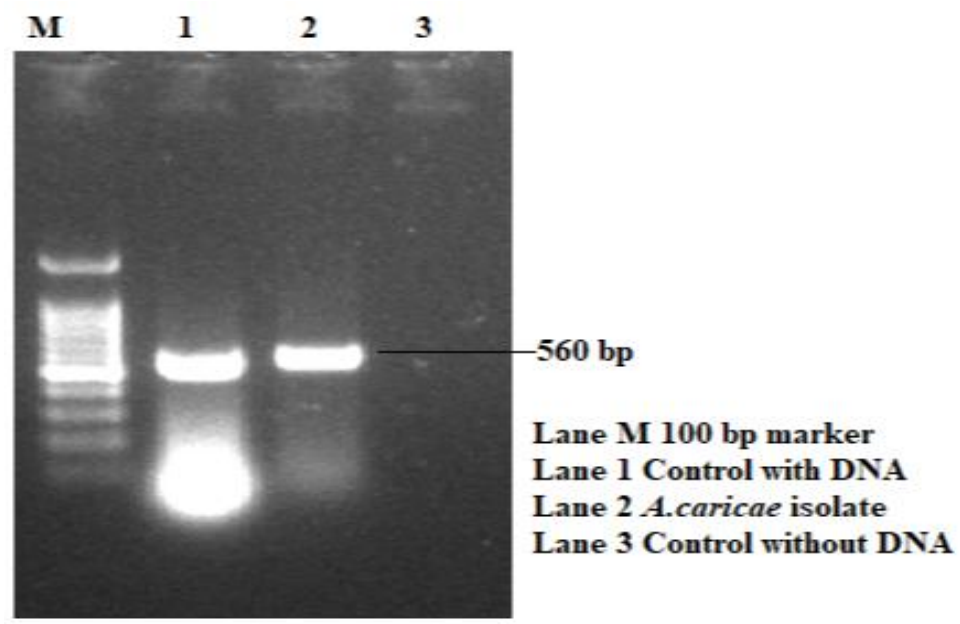

\section{Pathogenicity}

In order to prove the Koch's postulates, A.caricae isolate "Asp 1" was used to prove pathogenicity on two months old red lady papaya variety. Spore suspension was sprayed on the leaves and the inoculated plants were incubated in moist conditions by covering the plants with polythene covers (Fig. 3a). Inoculated plants showed typical yellow chlorotic lesions on the upper surface of the leaves twenty days after inoculation (Fig. 3b). Later the cholortic lesions turned to white spots with yellow margin. On thirty days after inoculation numerous black spores were found on the lower surface which appeared as black spots (Fig. 3c).

\section{Amplification by universal primers}

The Asperisporium caricae were subjected to polymerase chain reaction (PCR) for confirmation of pathogen at genus level using universal primers such as ITS 1 and ITS 4 with reaction mixture of $40 \mu \mathrm{l}$. The isolate showed the amplicon size of approximately 560 bp (Fig. 4). The isolate Asperisporium caricae was further sequenced and the same was submitted to NCBI Genbank. The accession number assigned was MK879405
In conclusion, the results of current study would be useful to fix parameters for exact identification of symptoms of black spot of papaya. Molecular confirmation could be made with universal primers ITS 1and ITS4

\section{Acknowledgement}

The authors are thankful to the Director, CPPS, Head of the Department and Professors of Department of Plant Pathology, TNAU, Coimbatore for providing support, guidance and financial assistance. The authors would like to acknowledge DST-FIST and UGCSAP-DRS1 for providing facilities at Department of Plant Pathology.

\section{References}

Adikaram, N. K. D., and Wijepala, M., 1995, Asperisporium black spot in Caricae papaya: A new disease in Srilanka. $J$. Nat. Sci. Council, 23(4): 213-219

Cumagun, C. J. R., Padilla, C. L., 2007, first record of Asperiosporium caricae causing black spot of papaya in the Philippines. Australasian Pl. Dis. Notes, 2:89-90.

Ellis, M. B, Holliday, P., 1972, Asperisporium caricae, CMI Descriptions of 
Pathogenic Fungi and Bacteria, 347: $1-2$.

Horticulture Statistics at a Glance. 2017. www.agricoop. nic.in

Minnis, A. M., Kennedy, A. H., Grenier, D. B., Rehner, S. A., Bischoff, J.F., 2011, Asperisporium and Pantospora (Mycosphaerellaceae) epitypifications and phylogenetic placement. Persoonia, Pp. $18-27$

Shantamma, S. G. Mantur, K. T. Rangaswamy, Bheemanagouda. Patil and Shivakumar Chinchure, 2014, Survey for black spot of papaya in selected districts of Southern Karnataka. Eco. Env. \& Cons. pp. (373-376).

Thiribhuvanamala, G., Alice,D., Parthasarathy, S., Karthikeyan, G.,
Krishna Reddy and Soorianatha Sundaram,K.,2016,Prevalence of black leaf spot of papaya caused by Asperisporium caricae in Tamil Nadu, India,Pest Management in Horticultural Ecosystems, Vol. 22, No. 2 pp 193-194.

Vawdrey, L. L., Grice, K.R.E. and Westerhuis, D., 2008, Field and laboratory evaluation of fungicides for the control of brown spot (Corynespora cassaiicola) and black spot(Asperisporium caricae) of papaya in north Quensland, Australia. Australian Pl. Pathol, 37:552-558

Ullasa, B. A., Sohi, H. S. and Rao, N. N. R. 1978. Occurrence of Asperisporium leaf spot of Papaya in India. Current Science. 47(7): 233-234.

\section{How to cite this article:}

Shreedevasena, S., S.K. Manoranjitham, L. Rajendran and Parimaladevi, R. 2019. Detection and Molecular Characterization of Black Spot Disease of Papaya (Carica papaya L.) Incited byAsperisporium caricae (Speg.) Maubl Int.J.Curr.Microbiol.App.Sci. 8(06): 511-517. doi: https://doi.org/10.20546/ijcmas.2019.806.059 